\title{
METODE PEMANASAN MODIFIKASI MEMPERPENDEK WAKTU TEMPUH RENANG GAYA BEBAS 50 METER
}

\author{
Rachma Zulfata ${ }^{1}$, Bambang Purwanto ${ }^{2}$, dan Harlina ${ }^{3}$ \\ Prodi Magister Ilmu Kesehatan Olahraga Fakultas Kedokteran Unair \\ Departemen Fisiologi Fakultas Kedokteran Unair \\ E-mail: rachmazulfata@yahoo.com
}

\begin{abstract}
Abstrak
Salah satu faktor yang mempengaruhi waktu tempuh renang yaitu metode pemanasan yang digunakan. Penelitian ini bertujuan untuk mengetahui pengaruh perbedaan prosedur pemanasan standar dengan modifikasi pada renang gaya bebas 50 meter terhadap waktu tempuh renang. Jenis penelitian yang digunakan yaitu eksperimen lapangan dengan rancangan pretest - posttest same sample design. Sampel pada penelitian ini berjumlah 26 atlet renang Sidoarjo Aquatic Club (SAC) menggunakan metode purposive sampling dan membagi kelompok dengan random sampling. Waktu tempuh yaitu melalui tes renang gaya bebas 50 meter. Metode standar yaitu (swim, kick, drill, swim), sedangkan metode modifikasi yaitu (swim, drill, kick, swim). Hasil pada penelitian ini menunjukkan bahwa terdapat perbedaan yang signifikan antara sebelum dan sesudah pemberian metode pemanasan modifikasi $(\mathrm{p}<0,05)$. Kesimpulan pada penelitian ini adalah metode pemanasan modifikasi memperpendek waktu tempuh renang gaya bebas 50 meter.
\end{abstract}

Kata kunci: Pemanasan modifikasi, waktu tempuh, renang gaya bebas 50 meter.

\section{PENDAHULUAN}

Pemanasan merupakan salah satu bentuk latihan fisik, dengan pemanasan diharapkan dapat mencegah cedera dan meningkatkan performa atlet (Marques \& Marinho, 2014). Selain itu pemanasan juga dapat mengoptimalkan kinerja melalui meningkatkan pengambilan oksigen dan kinetika, peningkatan suhu, meningkatkan aliran darah dan metabolisme, waktu reaksi, meningkatkan pembersihan laktat, serta meningkatkan distribusi oksigen (AlNawaiseh, 2013). Akan tetapi, metode pemanasan yang dilakukan di klub pembinaan prestasi olahraga renang masih berdasarkan pengalaman pelatih dan sampai saat ini efektifitas dari metode pemanasan tersebut belum diuji atau teruji.

Penelitian oleh Neiva et al. (2015) menunjukkan bahwa pemanasan panjang dengan jarak 1.800-meter dapat menurunkan performa renang sprint 100 meter. Penelitian lain dilakukan oleh Al-Nawaiseh (2013) pemanasan umum
(SWIM), kombinasi latihan plyometric di darat dan pemanasan renang (COMBO), dan renang 50 yard satu kali pada $90 \%$ dari catatan waktu terbaik (SHORT). Hasil dari penelitian ini heart rate (HR) pada SHORT lebih tinggi dari COMBO dan SWIM. Selain itu penelitian yang dilakukan oleh Neiva (2014), menyarankan dengan metode pemanasan aktif (pemanasan di darat, pemanasan di dalam kolam dengan modifikasi volume, dan pemanasan di dalam kolam dengan modifikasi intensitas serta efek waktu pemulihan setelah pemanasan) daripada pasif (penggunaan pemanas dari luar seperti shower panas, sauna dan jaket yang terpasang pemanas), Namun, belum ada penelitian yang memodifikasi urutan pemanasan standar (Swim, Kick, Drill, Swim) dengan volume 1.200 meter dengan volume yang sama namun tahapannya yang modifikasi (Swim, Drill, Kick, Swim) renang gaya bebas 50 meter. 


\section{METODE PENELITIAN}

Metode pada penelitian ini mengggunakan jenis metode field experiment atau eksperimen lapangan dengan menggunakan subjek manusia, dengan rancangan pretest - posttest same sample design. Pemilihan sampel dilakukan secara random berdasarkan kriteria inklusi dan eksklusi dan dengan rumus Lameshow 1990 didapatkan sampel sebanyak 26 atlet. Metode standar yaitu (swim, kick, drill, swim), sedangkan metode modifikasi yaitu (swim, drill, kick, swim). Teknik analisis data emnggunakan uji normalitas, uji levene, paired $t$-test, independent $t$-test dengan bantuan program SPSS 22 .

Tabel 1 Metode pemanasan standar

\begin{tabular}{lll}
\hline NO & JENIS PEMANASAN & DESKRIPSI PEMANASAN \\
\hline $\mathbf{1}$ & 300 meter renang gaya & 100 meter berenang gaya bebas normal \\
& bebas & 100 meter berenang gaya bebas nafas $5-1$ \\
& & 100 meter berenang gaya bebas normal \\
\hline $\mathbf{2}$ & 4 x 100 meter interval 1:50 & 25 meter kick bebas \\
& & 25 meter peningkatan panjang stroke \\
\hline $\mathbf{3}$ & \multirow{8}{*}{ x 50 meter interval :50 } & 50 meter drill \\
& & 50 meter membangun kecepatan \\
& & 25 meter pace -25 meter easy \\
& & 25 meter pace -25 meter easy \\
\hline $\mathbf{4}$ & 100 meter & Swim easy \\
\hline
\end{tabular}

Tabel 2 Metode pemanasan modifikasi

\begin{tabular}{lll}
\hline NO & JENIS PEMANASAN & DESKRIPSI PEMANASAN \\
\hline $\mathbf{1}$ & 300 meter renang gaya & 100 meter berenang gaya bebas normal \\
& bebas & 100 meter berenang gaya bebas nafas $5-1$ \\
& & 100 meter berenang gaya bebas normal \\
\hline $\mathbf{2}$ & \multirow{8}{*}{ x 50 meter interval :50 } & 50 meter drill \\
& & 50 meter membangun kecepatan \\
& & 25 meter pace -25 meter easy \\
& & 25 meter pace -25 meter easy \\
\hline $\mathbf{3}$ & 4 x 100 meter interval 1:50 & 25 meter kick bebas \\
& & 25 meter peningkatan panjang stroke \\
\hline $\mathbf{4}$ & 100 meter & Swim easy \\
\hline
\end{tabular}

\section{HASIL DAN PEMBAHASAN}

Analisis deskriptif dari kriteria sampel sesuai dengan variabel yang dikendalikan.

Tabel 3 Deskriptif kriteria variabel kendali

\begin{tabular}{lccccccc}
\hline \multirow{2}{*}{ Variabel } & $\mathrm{n}$ & \multicolumn{3}{c}{ Pemanasan Standar } & \multicolumn{3}{c}{ Pemanasan Modifikasi } \\
\cline { 3 - 8 } & & Min & Maks & $\begin{array}{c}\text { Rerata } \pm \\
\text { Simpangan Baku }\end{array}$ & Min & Maks & $\begin{array}{c}\text { Rerata } \pm \\
\text { Simpangan Baku }\end{array}$ \\
\hline Usia $($ thn $)$ & 16 & 12 & 18 & $13.63 \pm 1.86$ & 12 & 18 & $13.63 \pm 1.86$ \\
\hline Berat Badan $(\mathrm{Kg})$ & 16 & 29 & 75 & $49,06 \pm 13,13$ & 29 & 75 & $49,06 \pm 13,13$ \\
\hline Tinggi Badan $(\mathrm{m})$ & 16 & 1,36 & 1,79 & $1,57 \pm 1,29$ & 1,36 & 1,79 & $1,57 \pm 1,29$ \\
\hline IMT $\left(\mathrm{Kg} / \mathrm{m}^{2}\right)$ & 16 & 14,5 & 25,42 & $19,37 \pm 2,87$ & 14,5 & 25,42 & $19,37 \pm 2,87$ \\
\hline
\end{tabular}


Berdasarkan tabel 3 menunjukkan bahwa kelompok pemanasan standar maupun kelompok pemanasan modifikasi memiliki rerata yang sama karena pada penelitian ini subjek penelitian adalah sama.

Tabel 4 Tabel uji normalitas data waktu tempuh renang (detik)

\begin{tabular}{|c|c|c|c|c|c|}
\hline Variabel & Hasil & $\begin{array}{l}\text { Min } \\
(\mathrm{dtk})\end{array}$ & $\begin{array}{l}\text { Maks } \\
(\mathrm{dtk})\end{array}$ & $\begin{array}{c}\text { Rerata } \pm \\
\text { Simpangan } \\
\text { Baku (dtk) }\end{array}$ & $P$ \\
\hline \multirow{2}{*}{$\begin{array}{l}\text { Pemanasan } \\
\text { standar }\end{array}$} & $\begin{array}{l}\text { Pretest } \\
\text { standar }\end{array}$ & 25,89 & 38,54 & $31,87 \pm 3,95$ & 0,309 \\
\hline & $\begin{array}{l}\text { Posttest } \\
\text { standar }\end{array}$ & 25,50 & 38,76 & $31,57 \pm 3,99$ & 0,413 \\
\hline \multirow{2}{*}{$\begin{array}{l}\text { Pemanasan } \\
\text { Modifikasi }\end{array}$} & $\begin{array}{c}\text { Pretest } \\
\text { modifikasi }\end{array}$ & 25,26 & 38,88 & $32,84 \pm 4,36$ & 0,494 \\
\hline & $\begin{array}{c}\text { Posttest } \\
\text { Modifikasi } \\
\end{array}$ & 25,98 & 39,99 & $32,26 \pm 4,33$ & 0,620 \\
\hline
\end{tabular}

Keterangan : $p>0,05$ data berdistribusi normal

Berdasarkan tabel 4 termasuk dalam parametrik dan untuk menunjukkan bahwa data penelitian uji hipotesis dapat dilakukan dengan berdistribusi normal $(\mathrm{p}>0.05)$ sehingga Paired t test dan Independent $t$ test.

Tabel 5 Rerata hasil uji beda pretest - post test waktu tempuh sprint renang gaya bebas 50 meter pada metode pemanasan standar

\begin{tabular}{ccc}
\hline Variabel & Rerata \pm Simpangan Baku (detik) & p Sig. \\
\hline Pretest pemanasan standar & $31,87 \pm 3,95$ & 0,178 \\
\hline Posttest pemanasan standar & $31,57 \pm 3,99$ & \\
\hline Keterangan $: p>0,05$ data tidak & & \\
\hline
\end{tabular}

Keterangan : $p>0,05$ data tidak berbeda

Berdasarkan tabel 5 menunjukkan bahwa data pretestposttest metode pemanasan standar (Swim Kick Drill Swim) menunjukkan waktu tempuh post test sprint renang gaya bebas 50 meter lebih pendek. Hal ini dapat dilihat pada penurunan pada nilai rerata pretest dan posttest. Nilai $\mathrm{p}$ signifikansi sebesar $0,178>0,05$ yang artinya data tidak berbeda antara sebelum dan sesudah pemberian metode pemanasan standar.

Tabel 6 Rerata hasil uji beda pre test - post test waktu tempuh sprint renang gaya bebas 50 meter pada metode pemanasan modifikasi

\begin{tabular}{ccc}
\hline Variabel & Rerata \pm Simpangan Baku (detik) & p Sig. \\
\cline { 1 - 2 } Pretest pemanasan modifikasi & $32,84 \pm 4,36$ & 0,012 \\
\hline Posttest pemanasan modifikasi & $32,26 \pm 4,33$ & \\
\hline
\end{tabular}

Keterangan : $\mathrm{p}<0,05$ data berbeda bermakna

Berdasarkan tabel 6 data pretestposttest metode pemanasan modifikasi (Swim Drill Kick Swim) menunjukkan waktu tempuh post test sprint renang gaya bebas 50 meter lebih pendek. Hal ini dapat dilihat pada penurunan pada nilai rerata pretest dan posttest. Nilai $\mathrm{p}$ signifikansi sebesar $0,012>0,05$ yang artinya data berbeda bermakna antara sebelum dan sesudah pemberian metode pemanasan modifikasi. 
Tabel 7 Tabel statistik uji beda kelompok pemanasan standar dan modifikasi

\begin{tabular}{cccc}
\hline Pemanasan & $\mathrm{N}$ & Beda Rerata (detik) & p Sig. \\
\hline Standar & 16 & 0,30 & 0 \\
\hline Modifikasi & 16 & 0,58 & \\
\hline
\end{tabular}

Keterangan : $p>0,05$ tidak berbeda signifikan

Berdasarkan tabel 7 menunjukkan bahwa beda rerata hasil tes pada pemanasan standar lebih rendah daripada pemanasan modifikasi. Nilai $\mathrm{p}$ sebesar $0,359, \mathrm{p}>0,05$ yang artinya antara hasil pemanasan standard an modifikasi hasilnya tidak berbeda siginifikan.

\section{PEMBAHASAN}

Pada hasil analisis data dari tabel 6 diketahui rerata dan simpangan baku dari pre test pemanasan modifikasi yaitu 32,84 $\pm 4,36$ detik dan post test pemanasan standar yaitu $32,26 \pm 4,33$ detik. Beda rerata dari hasil keduanya yaitu 0,58 detik. Hasil ini menunjukkan bahwa pada posttest terjadi penurunan waktu tempuh.

Hasil uji beda paired t test pada pemberian metode pemanasan modifikasi menunjukkan bahwa nilai $\mathrm{p}$ sebesar 0,012. Hal ini mempunyai arti bahwa ada perbedaan yang bermakna antara hasil pre test dan post test pemanasan modifikasi karena nilai $\mathrm{p}<$ 0,05 .

Penurunan waktu tempuh posttest renang gaya bebas 50 meter pada metode pemanasan ini senada dengan penelitian yang dilakukan oleh Balilionis (2012) bahwa catatan waktu tempuh renang dengan pemanasan standar lebih singkat daripada tanpa pemanasan. Penelitian lainnya dilakukan oleh Neiva (2015) bahwa pemanasan standar dengan total jarak 1200 meter lebih rendah hasil catatan waktunya daripada pemanasan singkat dengan 600 meter dan pemanasan panjang 1800 meter.

Kecepatan renang dipengaruhi oleh pemanasan yang dilakukan. Pada penelitian ini menunjukkan bahwa setelah diberikan metode pemanasan modifikasi terjadi penurunan waktu tempuh posttest renang gaya bebas 50 meter. Hal ini kemungkinan disebabkan oleh kesesuaian tahapan gerakan (swim, drill, kick, swim) yang dilakukan pada metode pemanasan modifikasi menunjang dalam kecepatan renang gaya bebas 50 meter.

Kecepatan merupakan kemampuan untuk bergerak dalam waktu yang singkat (Lankor, 2007). Oleh karena itu gerakan yang dilakukan pada pemanasan tentunya mempengaruhi kecepatan dalam olahraga renang. Berenang orang bergerak maju dengan dayungan lengan, tangan dan kayuhan kaki. Namun, apabila untuk bergerak maju lebih cepat tidak hanya memperhatikan dayungan lengan, tangan dan kayuhan kaki saja, akan tetapi haruslah juga memperhatikan beberapa aspek yang berkaitan dengan stroke mechanics atau biomekanika dalam olahraga renang seperti daya dorong dan hambatan (Muhammad Murni, 2000). Hal ini dikarenakan, kecepatan dalam olahraga renang dipengaruhi oleh dua faktor, yaitu dorongan dan hambatan. Dorongan adalah daya (force) yang menyebabkan perenang dapat bergerak maju. Hal itu disebabkan oleh gerakan tangan dan kaki yang dilakukan perenang yang 
berhasil mendorong air ke belakang (Roepajadi, 2007).

Gerakan kaki pada gaya bebas dilakukan dengan dimulai tekanan pada pangkal paha, dilanjutkan dengan lecutan terkuat pada tungkai kaki bagian bawah dan serentak lecutan ujung kaki dengan jari-jarinya (Tetikay, 2011). Penjelasan hampir sama menurut Haller (2007) bahwa gerakan kaki dimulai dari pinggul bukan dari pergelangan kaki, perhatikan agar seluruh kaki naik turun serentak dan lurus, bukan hanya bagian bawah kaki. Sedangkan gerakan lengan pada renang gaya bebas berperan terutama sebagai tenaga pendorong atau penggerak di samping sebagai pengatur keseimbangan tubuh (Roeswan dan Soekarno (1979). Menurut Haller (2011) gerakan lengan dilaksanakan dalam dua tahap, yang satu dilakukan didalam air, sementara tangan menarik dan mendorong ke belakang dengan melajunya tubuh ke depan. Sedangkan yang satu lagi dilakukan di atas air dengan bergeraknya tangan ke depan sebelum masuk lagi ke dalam air untuk melakukan gerak selanjutnya. Untuk menghasilkan gerakan lengan yang baik dalam berenang, seorang perenang harus memperhatikan setiap tahap gerakan yang akan dilakukan. Menurut Subagyo (2008) siklus dari gerakan lengan gaya bebas terdiri dari 5 tahapan, yaitu entry, cats, pull-push, release, recovery. Berdasarkan penjelasan tersebut menunjukkan bahwa gerakan lengan pada renang gaya bebas berperan terutama sebagai tenaga pendorong atau penggerak di samping sebagai pengatur keseimbangan tubuh, dengan beberapa tahapan yaitu entry, cats, pull-push, release, dan recovery, yang dilakukan di dalam dan di luar air (Prasetyo \& Yunus, 2017). Selain itu menurut Marsudi (2009) gerakan lengan dalam gaya bebas merupakan sumber pokok dari dorongan. Menurut Counsilman
(1968) juga menegaskan bahwa kecepatan renang gaya bebas dihasilkan oleh $70 \%$ dorongan tangan dan 30\% dorongan kaki. Hal ini diperkuat oleh penelitian yang dilakukan oleh Asy'ari (2013), berdasarkan penelitian tersebut menunjukkan bahwa terdapat kontribusi yang signifikan antara dorongan tangan terhadap kecepatan renang gaya bebas dengan persentase sebesar 70,56\%, dan terdapat kontribusi yang signifikan antara dorongan kaki terhadap kecepatan renang gaya bebas dengan persentase sebesar 29,16\%. Sehingga, berdasarkan penjelasan diatas menunjukkan bahwa tangan mempunyai prosentase lebih besar untuk jalannya perenang daripada kaki. Oleh karena itu urutan pemanasan kick dilakukan setelah drill merupakan modifikasi yangs sesuai terhadap kecepatan renang gaya bebas. Hal tersebut menunjukkan bahwa urutan pemanasan dengan metode modifikasi lebih sesuai daripada metode pemanasan standar.

Pada metode pemanasan modifikasi terdiri dari swim, drill, kick, swim. Swim yaitu renang gaya bebas 300 meter dengan lima kayuan tangan satu kali ambilan nafas. Kemudian dilanjutkan dengan drill, latihan teknik atau drill dilakukan pada $8 \times 50$ meter interval 1 menit dengan rincian 25 race pace dan 25 easy (renang santai). Aktifitas ini bertujuan untuk pembangunan kecepatan dalam berenang gaya bebas. Setelah drill dilanjutkan dengan kick. Pukulan kaki atau kick pada penelitian ini dimaksudkan pada aktifitas memukul kaki pada posisi permukaan air dengan posisi tangan meruncing ke depan $4 \mathrm{x}$ 100 meter interval 1:50 dengan rincian 25 meter pukulan kaki (kick) dan 25 meter kayuan tangan panjang. Tujuan dari aktifitas ini tidak lain untuk menguatkan otot kaki. Pukulan kaki pada penelitian ini adalah pukulan kaki 
untuk dasar renang gaya bebas. Selanjutnya yang terakhir yaitu swim, swim adalah 100 meter easy swim atau renang gaya bebas sebagai upaya untuk pemulihan aktif. Berdasarkan penjelasan tersebut menunjukkan, bahwa swim 300 meter sebagai pemanasan awalan kemudian dilanjutkan dengan drill untuk pembangunan kecepatan. Selelah pembangunan kecepatan dilakukan kick untuk menguatkan otot kaki, dan yang terakhir easy swim. Berdasarkan penjelasan tersebut urutan gerakan pada metode pemanasan modifikasi menunjang dalam kecepatan. Setelah diberikan drill kemudian dilanjutkan dengan kick sehingga otot kaki lebih kuat. Kekuatan adalah kemampuan dari sistem syaraf otot untuk mengatasi ketahanan, melawan ketahanan dan menahan tahanan (Paulu Pesurney dalam M. Nasution, 2008). Kekuatan merupakan salah satu unsur kondisi fisik yang sangat dominan dan sangat dibutuhkan dihampir semua cabang olahraga. Kekuatan otot tungkai yang dimiliki seorang atlet dapat menentukan tingkat keberhasilan dalam melakukan gerakan tungkai yang maksimal, dimana dengan tungkai yang kuat dapat meningkatkan kecepatan pada renang gaya bebas (Lekso, 2013). Hal ini diperkuat oleh pernyataan dari Richard (2017) bahwa kick memiliki dampak signifikan pada kecepatan. Kick memainkan peran penting dalam menyeimbangkan dan menstabilkan trunk meningkatkan daya apung dan rotasi longitudinal. Ketika tubuh secara longitudinal berputar ke setiap sisi, tendangan mencegah anggota tubuh bagian bawah dari deviasi lateral pinggul. Selain itu, kick ini juga meningkatkan efektivitas propulsi tubuh bagian atas dengan mengangkat anggota tubuh bagian bawah, yang disebabkan oleh tekanan ke bawah yang terus menerus di bawah kaki. Berdasarkan hal tersebut sehingga kick yang ditaruh setelah drill merupakan kombinasi yang sesuai, dan berpengaruh terhadap kecepatan.

\section{KESIMPULAN DAN SARAN}

Kesimpulan pada penelitian ini adalah metode pemanasan modifikasi memperpendek waktu tempuh renang gaya bebas 50 meter. Selanjutnya perlu dilakukan penelitian dengan variabel meliputi kadar laktat darah dan HR karena pada penelitian hanya menguji pada hasil capaian waktu tempuh renang, perlu dilakukan kontrol aktivitas agar kondisi fisik atlet dan homoge, perlu dilakukan penelitian serupa terkait dengan pemberian metode pemanasan modifikasi pada gaya dan nomor yang lain.

\section{DAFTAR PUSTAKA}

Asy'ari, M.A. 2013. Kontribusi Dorongan Tangan dan Kaki Terhadap Kecepatan Renang Gaya Bebas. Jurnal Unesa, 1(3): 0-216.

Balilionis, G., 2012. Effects of different types of warm-up on swimming performance, reaction time, and dive distance. Journal of strength and conditioning research 26(12)/3297-3303.

Bishop D. 2003. Warm up II : Performance changes following active warm up and how to structure warm up. Sport Med 33:483-498

Counsilman, J.E. 1968. The Science of swimming. Englewood Cliffs, NJ: Prentice Hall.

Healler, David. 2007. BelajarBerenang. Bandung: Pionir Jaya Bandung.

Lekso, M.F. 2013. Pengaruh Metode Latihan dan Power Tungkai 
Terhadap Kecepatan

Berenang 50 Meter Gaya Dada

Pada Atlet Kelompok Umur IV

Perkumpulan Renang Spectrum

Semarang. Unnes Journal of Sport Sciences, (2): 1-14

Lembaga Akreditasi Nasional Keolahragaan (LANKOR). 2007. Teori Kepelatihan Dasar (Materi Untuk Kepelatihan

Tingkat Dasar). Jakarta:

Kementerian Pemuda dan

Olahraga.

M. Nasution. 2008. Penyusunan Program Latihan Kekuatan dan Daya Ledak. Semarang. Unnes

Marques, C, \& Marinho, DA. 2014. Warm-up and performance in competitive swimming. 319 330.https://doi.org/10.1007/s40 79-013-0117-y.

Marsudi, Imam. 2009. Renang Teori, Praktek \& Peraturan. Surabaya: Wineka Media.

Muhammad Murni. 2000. Renang. Jakarta: Depdikbud.

Neiva et al. 2014. Does Warm-Up Have a Beneficial Effect on 100-m Freestyle?. Journal of Sports Physiology and Performance, (9): $145-150$.

Neiva, et al. 2014. Warm-up and performance in competitive swimming. Sports Med (2014) 44:319-330
DOI:10.1007/s40279-013-0117

$\mathrm{y}$.

Neiva, et al. 2015. The effect of different warm-up volumes on the $\quad 100-\mathrm{m} \quad$ swimming performance: a randomized crossover study. Journal of strength and conditioning research 29(11)/3026-3036.

Prasetyo, E. \& Yunus, M. 2017. Hubungan antara Frekuensi Gerakan Kaki dengan Prestasi Renang Gaya Crawl 50 Meter. Indonesia Performance Journal, 1(2): 82-90.

Richards, James. 2017. The Effects of Varying Intensity Swimming an Kick Practice During a Warm Up on $200 \mathrm{~m}$ Freestyle Performance in Age Group Competitive Swimmers. University of Gloucestershire.

Roepajadi, Joesoef. 2007. Renang (Teknik, Prasarana dan Sistem Perlombaan). Surabaya: Unesa University Press.

Roeswan, dan Soekarno. 1979. Renang dan Metodhik. Jakarta : PT. Karya Unipress.

Subagyo. 2008. Teknik Renang. Bogor: Dahlia.

Tetikay, Robert. 2011. Renang (Teknik dan Metodik). Malang: Wineka Media. 